
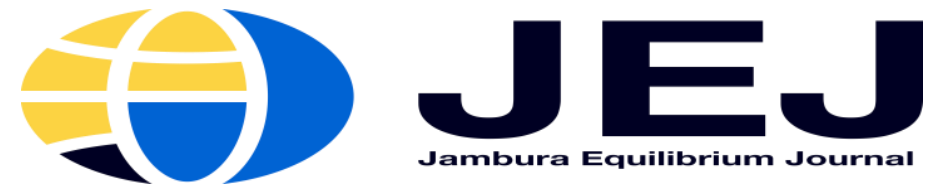

Volume 3. Issue 2. 2021

P-ISSN 2655-9110

E-ISSN 2656-0445

http://ejurnal.ung.ac.id/index.php/equij

\title{
Labor Decision Analysis In West Sumatera
}

Ridho Saputra ${ }^{1}$, Melty Roza Adry ${ }^{2}$

Faculty of Economics, Universitas Negeri Padang ${ }^{1,2}$

\begin{abstract}
This study aims to identify and analyze the performance of the economic sector on poverty in 2013-2017. The variables in this study are poverty as the dependent variable, and primary sector economic growth, secondary sector economic growth, and tertiary sector economic growth as independent variables. The data used in this study is secondary data obtained from BPS (Central Statistics Agency) Gorontalo Province and North Sulawesi Province. The analysis method used is panel data regression with a fixed effect model approach. In processing the data, the author uses the help of E-views 9 software. Based on the estimation results, it is found that the primary sector economic growth has a positive effect on poverty in Gorontalo Province. Meanwhile, the primary sector has a negative effect in North Sulawesi Province. Secondary sector economic growth has a negative effect on poverty in Gorontalo Province. Meanwhile, the secondary sector economic growth has a positive effect in North Sulawesi Province. Tertiary sector growth has a positive effect on poverty in Gorontalo Province. Meanwhile, the tertiary sector has a positive effect in North Sulawesi Province.
\end{abstract}

Keywords: Labor Work Decisions; Education; Gender; Age; Residential Area

\section{INTRODUCTION}

The decision to choose a job for workforce varies. it can be by being entrepreneurship, working with a wage system either on a contract or without a contract. This is due the rapid changes in the era of revolution 4.0 which have resulted in reducing amount of labor and opportunities in labor market. This forces the workforce to be required to be able to create their own business fields by means of entrepreneurship.

Borjas (2013) said there are two kind of relationships between working hours and wages, namely; first, an increase in the wage rate increases hours worked if the substitution effect dominates the income effect. As wages rise, recreation becomes more expensive and the substitution effect creates an incentive for workers to shift away from leisure consumption or demand to relax instead of consuming more goods. Then it will increase working hours. Second, an increase in the wage rate reduces working hours if the income effect dominates the substitution effect. When wages increase, income will increase which will increase the demand for leisure and reduce working hours

Adom (2019) said that work as an entrepreneur is a means of creating new products or services and production methods. School participation can 
encourage the workforce to easily enter work, then after completing school with high educational attainment, the workforce will be relatively easier to enter the world of work. Failla (2017) argues that some people choose entrepreneurial work as the best job, because they think that working as an entrepreneur is a flexible job. This is in accordance with Fritsch (2020) research which found that the decision to choose a job as an entrepreneur is not solely driven by income prospects but is influenced by freedom in decision-making and flexibility. Lehman (2018) stated that some people choose to work in the entrepreneurial sector because thay are waiting to be in the paid work sector.

According to Teichler (2015) education is a factor that greatly affects a person's work status. This is in line with research by Chen (2018), education has a positive effect on labor decisions. A higher level of education will increase one's productivity so that it will be rewarded with high wages (Fossen, 2013). People with relatively high education and skills will be a distinct advantage in competing in the world of work. This advantage will be a big consideration for companies and government agencies in recruiting workers, on the other hand, a labor with relatively low education and no skills will become an obstacle in competing in the world of work, making it difficult for them to find work.

The decision to work between the male and female age groups is different and so are the employment opportunities of the male and female. According to Nolan (2019), most workers in the entrepreneurial sector have a relatively old age and a relatively low level of education. the lower the level of education, the more likely the workforce is likely to be entrepreneurial. Whereas according to Zissimopoulos (2007), entrepreneur is mostly to have a highly educated entrepreneurs, meaning that the workforce that has a high level of education, is more likely to be selfemployed. Chen (2018) said that gender has a negative influence on labor decisions. This is because there are different roles between men and women. Lerchenmueller (2018) argues that in the field of science and technology women are more in the minority because the works produced are still less productive than men.

Based on data from BPS, it can be seen that residents aged more than 15 years are working as employee. It reaches 758,081 people while the number of entrepreneur is reaching 486,394 people. This indicates that the population in West Sumatra is most interested in working as employees. This happens because the community considers that work as an employee is a realistic job in terms of income that is more certain and can be obtained during the period set by the company.

Meanwhile, the highest percentage of the working population in the labor force was not completing elementary school, it was around 98.43 percent. The data above shows that the population aged more than 15 years old with the latest level of primary school education is higher than other education levels, meaning that the quality of the workforce in West Sumatra is still relatively low due to low levels of education. Furthermore, the 50-54 years age are the highest population in the workforce in West Sumatra, it shows the more experienced and more skilled at work then the opportunity for the workforce to work is higher.

Based on the explanation above, it is necessary to analyze the determinants of labor decisions in West Sumatra, as with the right work decisions by the labor force will lead to better income. From the above phenomena, the authors are interested in analyzing the "Determinants of Labor Decisions in West Sumatra". 


\section{METHODOLOGY}

The data used in this study are secondary data from BPS-Sakernas in 2018. The method used is a multinomial logistic regression analysis model. In the multinomial logistic regression output obtained is a risk ratio, not an odds ratio (Harlan, 2018).This study uses a Multinomial Logit model with three categories, it consists of two logit functions, including the following;

The logit function for $\mathrm{Y}=2$ is relative to the logit function for $\mathrm{Y}=1$

The logit function for $Y=3$ is relative to the logit function for $\mathrm{Y}=1$

Where; category $\mathrm{Y}=1$ is the comparison category.

The logit model is expressed as follows:

$\mathrm{Li}=\operatorname{In}\left[\frac{p_{(x i)}}{1-P_{(x i)}}\right] \mathrm{Zj}=\beta_{0}+\beta_{1} X_{1}+\beta_{2} X_{2}+$ $\beta_{3} X_{3}+\cdots+\beta_{n} X_{n}+\mathrm{e}$

With:

a) The logit function of a work decision as a contract worker for a decision to work as an entrepreneur: $\mathrm{Z} j(\mathrm{X})=\operatorname{In} \operatorname{Pr}(\mathrm{Y}=2 \mid \mathrm{x})=\beta_{0}+$ $\beta_{1} X_{1}+\beta_{2} X_{2}+\beta_{3} X_{3}+\cdots+$ $\beta_{n} X_{n}+\mathrm{e}$ b) The logit function of a work decision as a wage labor without a contract against a work decision as an entrepreneur:

$\mathrm{Zj}(\mathrm{X})=\operatorname{In} \operatorname{Pr}(\mathrm{Y}=3 \mid \mathrm{x})=\beta_{0}+$ $\beta_{1} X_{1}+\beta_{2} X_{2}+\beta_{3} X_{3}+\cdots+$ $\beta_{n} X_{n}+\mathrm{e}$

Where $\mathrm{Zj}$ is the probability of circumstances or the labor force's decision in choosing a work decision, $\beta_{0}$ is a constant, $\beta_{1}, \beta_{2}, \beta_{3}$ is the regression coefficient of each variable, $\mathrm{X} 1$ is the level of education, $\mathrm{X} 2$ is gender, $\mathrm{X} 3$ is age, $\mathrm{X} 4$ is the region where stay, $\mathrm{e}$ is the term of error.

\section{RESULTS AND DISCUSSION}

The multinomial logistic regression method is used to see the effect of independent variables on the dependent variable where the dependent variable is polychotomous, which has a nominal or ordinal scale with more than two categories, namely label one, label two and label three. This presented in the following table.

Table 1

G Test and the Determinant Coefficient of Labor Decisions in West Sumatra 2018

\begin{tabular}{ll}
\hline Pseudo R2 & 0,0597 \\
LR statistic & 1739,80 \\
Prob (LR statistic) & 0,0000 \\
Log Likelihood & $-13699,945$ \\
\hline
\end{tabular}

Source: Data Processed

From the $G$ test, it can be said that the determinant coefficient of labor decisions in West Sumatra is 0.0597, so it can be said that the contribution of the variables of education level (X1), gender (X2), age (X3), and area of residence (X4) on labor decisions ( $\mathrm{Y}$ ) is $5.97 \%$ while the remaining $94.03 \%$ is explained by other variables. The following table shows the results of the estimation of multinomial logistic regression in this study: 
Table 2

Estimation Results of Parameters and Multinomial Logistic Regression RRR

\begin{tabular}{|c|c|c|c|c|c|c|}
\hline $\begin{array}{l}\text { Keputusan } \\
\text { Kerja }\end{array}$ & Variabel & $\begin{array}{l}\text { B. } \\
\text { Parameter }\end{array}$ & SE & Sig & $\begin{array}{l}\text { Exp } \\
\text { (B) }\end{array}$ & Dy/dx \\
\hline \multirow{7}{*}{$\begin{array}{l}\text { Bekerja } \\
\text { upahan } \\
\text { kontrak }\end{array}$} & SLTP (D1 X1) & $-0,306$ & 0,057 & $0,000^{*}$ & 0,735 & 0,045 \\
\hline & SLTA (D2 X1) & 0,286 & 0,049 & $0,000 *$ & 1,331 & 0,068 \\
\hline & $\begin{array}{l}\text { Perguruan Tinggi (D3 } \\
\text { X1) }\end{array}$ & 1,610 & 0,060 & $0,000 *$ & 5,003 & 0,383 \\
\hline & Jenis Kelamin (X2) & 0,081 & 0,038 & $0,034 * *$ & 1,084 & 0016 \\
\hline & Umur (X3) & $-0,002$ & 0,001 & $0,053 * * *$ & 0,997 & - \\
\hline & Wilayah Tempat & $-0,091$ & 0,039 & $0,020 * *$ & 0,912 & 0,000 \\
\hline & $\begin{array}{l}\text { Tinggal (X4) } \\
\text { Konstanta }\end{array}$ & -1.001 & 0.074 & 0,000 & 0,367 & $\begin{array}{r}0,019 \\
-\end{array}$ \\
\hline \multirow{8}{*}{$\begin{array}{l}\text { Bekerja } \\
\text { upahan } \\
\text { tanpa } \\
\text { kontrak }\end{array}$} & SLTP (D1 X1) & $-0,467$ & 0,067 & $0,000 *$ & 0,626 & - \\
\hline & SLTA (D2 X1) & $-0,439$ & 0.063 & $0.000 *$ & 0.644 & 0,033 \\
\hline & & & & & & 0,046 \\
\hline & $\begin{array}{l}\text { Perguruan Tinggi (D3 } \\
\text { X1) }\end{array}$ & $-0,649$ & 0,120 & $0,000 *$ & 0,522 & $\begin{array}{r}- \\
0,086\end{array}$ \\
\hline & Jenis Kelamin (X2) & 1,109 & 0,054 & $0,000^{*}$ & 3,033 & 0,106 \\
\hline & Umur (X3) & 0,000 & 0,001 & 0,902 & 1,000 & 0,000 \\
\hline & $\begin{array}{l}\text { Wilayah Tempat } \\
\text { Tinggal (X4) }\end{array}$ & 0,063 & 0,051 & 0,220 & 1,065 & 0,008 \\
\hline & Konstanta & $-2,044$ & 0,097 & 0,000 & 0,129 & - \\
\hline
\end{tabular}

Source: Data Processed

Based on the estimation results, it shows that education with a diploma, junior high school, senior high school and first degree and gender has a significant effect on the decision to work as employee with contract and without a contract compared to entrepreneurship. The age and area of residence have a significant effect on the decision to work as employee with contract and without a contract compared to entrepreneurship with significance $<\alpha=$ $0.01,<\alpha=0.05$ and $<\alpha=0.10$, but the variable age and area of residence do not have a significant effect on the decision. wage employment without a contract compared to entrepreneurship. Significance $>\alpha=0.10$.

\section{Wald test (z statistik)}

Wald test is used to test the effect of each independent variable on the dependent variable. After testing the hypothesis, it can be seen that the independent variable has a significant effect on the dependent variable with a probability value (LR statistic) and the contribution of the independent variable to the dependent variable is $5.97 \%$. From the results of this partial test it can be seen that age and area of residence do not have a significant effect on the decision to work as employee without a contract on than being an entrepreneurship, with the probability values are 0.902 and 0.220 , respectively.

\section{Discussion}

The Influence of Education Level on Workforce Decisions in West Sumatra 
Based on the results of the multinomial logistic regression analysis, the education variable with a junior high school graduated has a significant effect on contract and non-contract wage work decisions compared to entrepreneurship. With parameter values of -0.306 and -0.467 and RRR of 0.735 and 0.626 , which means that a junior high school graduated has a negative and significant effect on wage with contract work decisions and wages without a contract compared to entrepreneurship in West Sumatra.

While those who are high school graduated and first degree has a significant effect on contract wage work decisions compared to entrepreneurship. The parameter value for high school graduated is 0.286 , first degree is 1.610 and RRR for high school diploma is 1.331 , first degree is 5.003 which means that high school graduate has a positive and significant effect on contract wage work decisions compared to entrepreneurship in West Sumatra. This happens because the workforce with high school and first degree graduate are equipped with knowledge and skills. The higher the education of the workforce, the higher the skills of that workforce, so that the workforce can flexibly choose jobs that are desired (Suriastini, 2006).In accordance with the theory of human capital, a person can increase his income by increasing education (Mankiw, 2003). The results of this study are consistent withChen (2018) which states that low education will cause people to choose entrepreneur as their job, while higher education people will choose being employee with a contract as the main job.

\section{The Influence of Gender on Workforce Decisions in West Sumatra}

Based on the results of the multinomial logistic regression analysis, the gender has a significant and positive effect on the labor decision to work with or without contract compared to entrepreneurship in West Sumatra with parameter values of 0.081 and 1.109 and RRR of 1.084 and 3.033. This shows that men are dominant in entering the job as employee compared to women. Meanwhile, women are dominant in entering entrepreneurial jobs. In accordance with the theoretical basis presented by Samuelson (2003), women experience discrimination at the workforce, due to differences in levels of education and experience so that women do not easily enter certain highpaying professions. The same thing is also supported by Todaro (2011) that women have less access to education, wage sector employment, and health insurance.

The results of this study are in accordance with Chen (2018) which found that gender has an influence on labor decisions. This is because there are different roles between men and women. Where women with the responsibility of taking care of the household make it difficult to decide to be employee. This is also in accordance with Beblo (2018) research which states that there is a significant gender gap in preferences for work. However, contrary to the research of Zissimopoulos \& Karoly (2007) Nolan (2019), it is stated that to enter entrepreneurial work are dominated by men rather than women.

\section{The Effect of Age on Labor Decisions in West Sumatra}

Age has a significant and negative effect on work decisions in West Sumatra. The parameter value is -0.002 and RRR is 0.997 . These results indicate that age will affect the chances of the workforce in deciding to work as employee with contract wage compared to entrepreneurship. Meanwhile, age does not have a significant effect on the decision to work without a 
contract. This shows that with increasing age, those who work without a contract will will be appointed to be permanent workers or without a contract.

The results of this study are consistent with research conducted by Suriastini (2006) which states that age is a major factor affecting parameters of job changes. Increasing the age of the workforce can reduce opportunities to change jobs, enter the labor market, change jobs, and change occupations, income. This means that as they get older, the greater the decision to work permanently or without a contract until retirement.

\section{The Influence of Residence Area on Labor Decisions in West Sumatra}

Based on the results of multinomial logistic regression analysis, the area of residence variable has a significant and negative effect on the decision to work as employee with contract compared to entrepreneurship while the area of residence variable has an insignificant effect on the decision of wage employment without a contract compared to entrepreneurs in West Sumatra. This suggests that the labor force living in urban areas want to be employee without contract. Meanwhile, most of the rural labor want to be employee with contract.

The labor force that lives in urban areas tends to enter jobs without a contract because they have competent experience and skills so that they tend to decide to enter permanent jobs, where the income they receive is relatively higher. On the other hand, the workforce living in rural areas decides to enter work without a contract because it is inseparable from lack of competence in experience and skills. The results of this study are in accordance with research conducted by Chen (2018), the area of residence has a positive influence on labor decisions. This study identifies that rural areas have a relatively high poverty rate and various other economic problems, so that the workforce in rural areas will tend to decide more quickly to work such as in the agricultural sector or other jobs.

\section{CONCLUSION}

From the estimation results by using multinomial regression, it found that:

1. Education has a significant influence on the decision to work as employee with or withour contract compared to being entrepreneur in West Sumatra, meaning that the higher the level of education, the greater the opportunity for the workforce to decide to enter contract wage work and without a contract compared to entrepreneurship.

2. Gender has a significant influence on the decision to work to work as employee with or withour contract compared to being entrepreneur in West Sumatra, meaning that gender will affect the opportunities for the workforce to decide to enter contractfree and contract-free wage work compared to entrepreneurship.

3. Age has a significant influence on the decision to work as employee with contract compared to being entrepreneur in West Sumatra while age has no significant effect on the decision to work wage without a contract compared to entrepreneurship

4. The area of residence has a significant effect to work as employee with contract compared to being entrepreneur in West Sumatra while the area of residence variable has an insignificant effect on the decision of wage employment without a contract compared to entrepreneurs in West Sumatra. 


\section{REFERENCES}

Adom, E., \& Affum- osei, E. (2019). Entrepreneurship as a career choice : The impact of locus of control on aspiring entrepreneurs ' opportunity recognition. Journal of Business Research, 98 (October 2018), 227235.

https://doi.org/10.1016/j.jbusres.2019. 02.006

Agu, P., Chinonso, U., \& Vivienne, C. (2019). The International Journal of Towards a responsible entrepreneurship education and the future of the workforce. The International Journal of Management Education, (August 2018), 100300. https://doi.org/10.1016/j.ijme.2019.05 .001

Badan Pusat Statistik Provinsi Sumatera Barat. (2018). Keadaan angkatan Kerja di Provinsi Sumatera Barat Agustus 2018.

Beblo, M., \& Gorges, L. (2018). On the nature of nurture. The malleability of gender differences in work preferences. Journal of Economic Behavior and Organization, 151, 1941.

https://doi.org/10.1016/j.jebo.2018.05 .002

Borjas, George. j. (2013). Labor Ekonomics (edition 6). New York: McGraw-Hill.

Chen, Suang. (2018). International Journal of Educational Development Education and transition to work: Evidence from Vietnam, Cambodia and Nepal. International Journal of Educational Development, 61(December 2017), 92-105. https://doi.org/10.1016/j.ijedudev.201 7.12.006

Failla, V., Melillo, F., \& Reichstein, T. (2017). Journal of Business Venturing Entrepreneurship and employment stability - Job matching, labour market value, and personal commitment. Journal of Business Venturing, 32(2), 162-177. https://doi.org/10.1016/j.jbusvent.201 7.01.002

Fossen, F. M., \& Bu, T. J. M. (2013). Economics of Education Review The returns to education for opportunity entrepreneurs , necessity entrepreneurs, and paid employees. 37, 66-84. https://doi.org/10.1016/j.econedurev. 2013.08.005

Fritsch, M., Sorgner, A., \& Wyrwich, M. (2020). Self-employment and wellbeing across institutional contexts. Journal of Business Venturing, (July 2019), 105946. https://doi.org/10.1016/j.jbusvent.201 9.105946

Harlan, Johan. (2018). Analisis Regresi Logistik. Depok: Gunadarma.

Hasanah, N. (2003). Perbedaan Gender Di Tempat Kerja Staf Pengajar Jurusan Manajemen Fakultas Ekonomi dan Bisnis Universitas Jambi. 1-8.

Jhingan. (2012). Ekonomi Pembangunan dan Perencanaan. Jakarta: Rajawali.

Johnson, R. D. (2010). Extracting a revised labor supply theory from Becker' $\mathrm{s}$ model of the household. Journal of Socio-Economics, 39(2), 241-250. https://doi.org/10.1016/j.socec.2009.1 0.011

Lehmann, H., \& Pignatti, N. (2018). Informal employment relationships and the labor market: Is there segmentation in Ukraine. Journal of Comparative Economics, (July), 0-1. https://doi.org/10.1016/j.jce.2018.07. 011

Lerchenmueller, M. J., \& Sorenson, O. (2018). The gender gap in early career transitions in the life sciences. Research Policy, 47(6), 1007-1017. https://doi.org/10.1016/j.respol.2018. 02.009 
Mankiw, N. Gregory. (2003). Pengantar Ekonomi. Jakarta: Erlangga.

Nolan, A., \& Barrett, A. (2019). The Journal of the Economics of Ageing The role of self-employment in Ireland ' $s$ older workforce. The Journal of the Economics of Ageing, 14(August 2017), 100201.

Samuelson, P. A. \& N. (2003). Ilmu Mikro Ekonomi (Edisi Baha). Jakarta: PT Media Global Edukasi.

Simanjuntak, P. J. (1998). Pengantar Ekonomi Sumber Daya Manusia (Edisi Kedu). Jakarta: Fakultas Ekonomi Universitas Indonesia.

Suriastini, N. W. (2006). Hubungan Umur Dengan Perubahan Pekerjaan: Suatu Aplikasi Metaanalisis Dalam Ukuran Sampel. 17(2), 1-12.

Teichler, U., \& Centre, I. (2015). Education and Employment. In International Encyclopedia of Social \& Behavioral Sciences (Second Edi, Vol. 7). https://doi.org/10.1016/B978-0-08097086-8.92059-2

Todaro, Michael. P. \& Smith. Stephen. C. (2011). Pembangunan Ekonomi. Jakarta: Erlangga.

Zissimopoulos, J. M., \& Karoly, L. A. (2007). Transitions to selfemployment at older ages: The role of wealth, health, health insurance and other factors. 14, 269-295. https://doi.org/10.1016/j.labeco.2005. 08.002 